\title{
Determination of Metal Concentration in Air, Soil and Water Samples at Some Selected Flow Stations in Delta State, Nigeria
}

\author{
Valentine Ifenna Onwukeme ${ }^{1}$, Omonigho Frank Etienajirhevwe ${ }^{2, *}$ \\ ${ }^{1}$ Deparment of Pure and Industrial Chemistry, Nnamdi Azikiwe University, Awka, Anambra State, Nigeria \\ ${ }^{2}$ Chemistry Unit, Department of Science Laboratory Technology, Delta State Polytechnic, Otefe, Oghara, Nigeria
}

Email address:

omonigho4jesus@yahoo.com (O. F. Etienajirhevwe)

*Corresponding author

\section{To cite this article:}

Valentine Ifenna Onwukeme, Omonigho Frank Etienajirhevwe. Determination of Metal Concentration in Air, Soil and Water Samples at Some Selected Flow Stations in Delta State, Nigeria. American Journal of Physical Chemistry. Vol. 9, No. 1, 2020, pp. 9-15. doi: 10.11648/j.ajpc.20200901.12

Received: April 6, 2020; Accepted: April 22, 2020; Published: May 27, 2020

\begin{abstract}
This study involves the determination of metal concentration in air, water and soil samples at some selected flow stations in Delta State Nigeria. This is to ascertain the level of pollution of the environment by the companies located in the areas. Soil, air and water samples were collected in triplicate for a period of three months. The metals were analyzed by Atomic Absorption Spectrophotometer (AAS) after digestion and extraction. Results of water analysis showed mean copper in the ranged of $0.14 \pm 0.03,0.03 \pm 0.02,0.35 \pm 0.00$ and $0.23 \pm 0.07 \mathrm{mg} / \mathrm{L}$ while zinc ranged from $0.06 \pm 0.02,0.11 \pm 0.04,0.29 \pm 0.16$ and $2.52 \pm 0.97 \mathrm{mg} / \mathrm{L}$ for PPL, WRPC, AFS and TPS respectively. Cadmium was $0.06 \pm 0.01$ and $0.05 \pm 0.05 \mathrm{mg} / \mathrm{L}$ at WRPC and AFS. Mean concentration of lead in soil ranged from $1.09 \pm 0.05,0.95 \pm 0.21,1.69 \pm 0.23$ and $0.3 \pm 0.06 \mathrm{mg} / \mathrm{kg}$; cadmium ranged from $5.26 \pm 0.53,20.45 \pm 1.84,67.48 \pm 11.35$ and $0.36 \pm 0.15 \mathrm{mg} / \mathrm{kg}$; zinc ranged from $38.26 \pm 28.50,116.41 \pm 6.71,682.33 \pm 44.82$ and $200.44 \pm 20.67 \mathrm{mg} / \mathrm{kg}$ while copper ranged from $306.17 \pm 6.66,39.64 \pm 8.37,361.60 \pm 30.06$ and $163.33 \pm 9.55 \mathrm{mg} / \mathrm{kg}$ for PPL, AFS, WRPC and TPS respectively. Results of air analysis showed of concentrations of lead to ranged from $0.05-0.11 \mu \mathrm{g} / \mathrm{kg}$, cadmium $0.50-1.89 \mu \mathrm{g} / \mathrm{kg}$, zinc $0.05-1.15 \mu \mathrm{g} / \mathrm{kg}$ and copper $0.17-0.55 \mu \mathrm{g} / \mathrm{kg}$. The results of the analysis found the water to be most polluted followed by the soil while the air was the least. The results obtained from the study found some locations polluted while other slightly polluted. The pollution was therefore attributed to the nature of activities carried out at the various locations. It was therefore recommended that humans should consider the consequences for our actions and work to improve air, water and soil quality for future generation
\end{abstract}

Keywords: Heavy Metals, Pollution, Location, Flow Station and Samples

\section{Introduction}

The atmosphere is the gaseous envelope that surrounds the earth and constitutes the transition between its surface and the vacuum of space [1].. Concerns about the air quality have probably been around as long as mankind; from the moment fire was invented, air pollution became a problem [2].

The pollution of the aquatic environment with organic and inorganic contaminants has become a world problem during recent years because they are indestructible and most of them have toxic effects on organism [3]. Among environmental pollutants, metals are of particular concerns due to their potential toxic effects and ability to accumulate in aquatic ecosystem [4].

Deposition of contaminants on soil may be deleterious to soil growth and soil productivity and may also produce crops containing unacceptably high level of contaminants for animal and human health; serious systematic health problems could develop as a result of excessive accumulation of dietary contaminants in the body [5].

Elevated levels of gaseous contaminants have been observed in the vicinity of certain industries like refineries, ports, and near busy roads and within urban areas in general [6]. The measured level of these contaminants serves as an 
index of air pollution $[7,8]$.

The presence of elemental concentration in the atmosphere of one or more contaminants of combination thereof in such quantities of such duration may cause injury to human health, plant or animal life or properties (materials) or may reasonably interfere with the comfortable enjoyment of life or properties or the conduct of business [9].

Breathing is not optional, it is essential even for a short time and air has to be used as it is found and "the air we receive at our birth and resign only when we die is the first necessity of our existence" [2].

Analysis of air, water and soil shows the presence of numerous substances in trace amounts some of which could be explained to emanate from either natural or anthropogenic that is, man-made source activities; other substances could be formed indirectly from chemical process in the atmosphere. Hence, the combination of a source to the atmosphere varies according to its emission characteristics and the emitted substance [10].

Despite the essential ingredients of air, water and soil, their qualities has been historically variable and frequently to the detriments of human health. Nevertheless, our quality of life dramatically improved during the twentieth century. Now however, a growing body of research has found that certain substances may affect human health at lower concentration than had previously been thought. This concern has heightened public anxiety to the importance of improving and managing the quality of air, soil and water is protected and managed for future generations (Department of the Environment [11].

The aim and objective of this work is to determine the presence of metal concentration in soil samples in air, soil and water at some selected flow stations in Delta State, Nigeria

\section{Methods}

\subsection{Soil Sampling}

Soil samples were collected at the (3) sampling locations and at the control site with the aid of a soil auger at depth 0 $15 \mathrm{~cm}$ and $15-30 \mathrm{~cm}$. The soils were put in black polythene bags labeled and were transported to the laboratory for chemical analysis. Three soil samplings were carried out at each location within the months of February, March and April 2017 and a total of eighteen (18) soil samples were collected for the three locations and six (06) from the control site making a total of twenty four (24) samples

\subsection{Water Sampling}

Water samples were collected at (3) sampling locations and at the control site with the aid of a water sampler. The water was collected in an acid washed and distilled water rinsed polypropylene bottles labeled and were transported to the laboratory for chemical analysis. Three water samplings were carried out for each location within the months of February, March and April 2017 and a total of nine (9) samples were collected for the three locations and three (3) from the control site making a total of twelve (12) samples.

\subsection{Air Samplings}

Heavy metals components were collected by the use of particulate matter sampler impregnated with a glass fibre filter paper which was kept at the sampling site for fourteen days. Triplicate sampling was carried out within the months of February, March and April 2017 for the three study locations and the control site.

\section{Analysis}

\subsection{Digestion and Extraction of Samples}

\subsubsection{Soil Samples}

Soil samples collected from all the locations were tested for heavy metals concentrations. The soil samples collected were dried $\left(80 \pm 10^{\circ} \mathrm{C}\right)$ for 10 hours in a hot air oven, homogenized and sieved for extraction $\mathrm{Pb}, \mathrm{Cd}, \mathrm{Hg}, \mathrm{As}, \mathrm{Zn}$, and $\mathrm{Cu}$ according to Ekeayanwu [5].

\subsubsection{Air Samples}

The heavy metal air contaminants retained onto the fibre glass filter $(20 \times 25 \mathrm{~cm})$ were cut into small pieces and were digested for thirty minutes in $100 \mathrm{~mL}$ hydrochloric acid over a low heat of $50^{\circ} \mathrm{C}$ in an oven. The solid in the solution was extracted with $2 \mathrm{M}$ hydrochloric acid and was evapourated nearly to dryness which was then re - dissolved in $10 \mathrm{~mL}$ concentrated hydrochloric acid with the addition of ten drops of $1 \mathrm{M}$ trioxonitrate $(\mathrm{V})$. The resulting solution was transferred into a $50 \mathrm{~mL}$ volumetric flask and was made to volume with distilled water after which it was filtered through blue ribbon filter paper (S\&S 11589) into another volumetric flask which were kept in the refrigerator for metal concentration analysis [12].

\subsubsection{Water Samples}

Thewater samples were acidified with trioxonitrate (v) acid (1:1) and were kept in the refrigerator until analysis.

\subsection{Heavy Metals Analysis}

$100 \mathrm{~mL}$ each of the digested and extracted samples was analyzed for lead $(\mathrm{Pb})$, Cadmium $(\mathrm{Cd})$, Mercury $(\mathrm{Hg})$, Arsenic (As), Zinc ( $\mathrm{Zn})$ and Copper $(\mathrm{Cu})$ by using atomic absorption spectrophotometer. [5].

\subsection{Statistical Analysis}

Data obtained from the experiments were checked by using Minitab statistical package. Descriptive statistical analysis was used to check the means and standard deviations of the collected date. Inter - station comparisons were carried out to check the differences between the locations using parametric analysis of variance (ANOVA). Dunnette multiple comparison tests were further carried out to determine the location of significant differences compared with the control site. 


\section{Results}

Table 1. Results of Metals concentration $(\mathrm{mg} / \mathrm{L})$ in water.

\begin{tabular}{|c|c|c|c|c|c|c|c|c|c|c|c|c|}
\hline \multirow{2}{*}{ METALS } & \multicolumn{3}{|c|}{ TRANSCORP POWER (Control) } & \multicolumn{3}{|c|}{ WARRI REFINERY } & \multicolumn{3}{|c|}{ AMUKPE FLOWSTATION } & \multicolumn{3}{|c|}{ PLATFORM PETROLEUM } \\
\hline & Feb & Mar & Apr & Feb & Mar & Apr & Feb & Mar & Apr & Feb & Mar & Apr \\
\hline $\mathrm{Pb}$ & BDL & BDL & BDL & BDL & BDL & BDL & BDL & BDL & BDL & BDL & BDL & BDL \\
\hline $\mathrm{Cd}$ & BDL & $\mathrm{BDL}$ & $\mathrm{BDL}$ & $\mathrm{BDL}$ & $\mathrm{BDL}$ & BDL & 0.05 & 0.06 & 0.06 & 0.10 & 0.03 & 0.01 \\
\hline $\mathrm{Hg}$ & BDL & BDL & BDL & BDL & BDL & BDL & BDL & BDL & BDL & BDL & BDL & BDL \\
\hline As & BDL & BDL & BDL & BDL & BDL & BDL & BDL & BDL & BDL & BDL & BDL & BDL \\
\hline $\mathrm{Zn}$ & 0.11 & 0.07 & 0.14 & 0.09 & 0.05 & 0.05 & 0.47 & 0.25 & 0.16 & 2.87 & 3.26 & 1.42 \\
\hline $\mathrm{Cu}$ & 0.03 & 0.05 & 0.02 & 0.15 & 0.17 & 0.11 & 0.36 & 0.36 & 0.33 & 0.31 & 0.19 & 0.20 \\
\hline
\end{tabular}

BDL: Below Detection Limit

Table 2. Mean metals concentration of Water compared with Water Guideline.

\begin{tabular}{llll}
\hline \multirow{2}{*}{ LOCATION/ GUIDELINE } & \multicolumn{2}{l}{ Metals (mg/L) \pm SD } & \\
\cline { 2 - 4 } & Cd & Zn & Cu \\
\hline Transcorp Power (Control) & BDL & $0.11 \pm 0.04$ & $0.03 \pm 0.02$ \\
Warri Refinery & $0.06 \pm 0.01$ & $0.29 \pm 0.16$ & $0.35 \pm 0.00$ \\
Amukpe F/Station & $0.02 \pm 0.05$ & $2.52 \pm 0.97$ & $0.23 \pm 0.07$ \\
Platform Petroleum & BDL & $0.06 \pm 0.02$ & $0.14 \pm 0.03$ \\
WHO & $\mathbf{0 . 0 1}$ & 15.00 & 0.01 \\
\hline
\end{tabular}

Table 3. Metal concentrations in soil ( $\mathrm{mg} / \mathrm{kg})$.

\begin{tabular}{|c|c|c|c|c|c|c|c|c|c|c|c|c|}
\hline \multirow{2}{*}{ METALS } & \multicolumn{3}{|c|}{ TRANSCORP POWER (Control) } & \multicolumn{3}{|c|}{ WARRI REFINERY } & \multicolumn{3}{|c|}{ AMUKPE F/STATION } & \multicolumn{3}{|c|}{ PLATFORM PETROLEUM } \\
\hline & Feb & Mar & Apr & Feb. & Mar & Apr & Feb & Mar & Apr & Feb & Mar & Apr \\
\hline $\mathrm{Pb}$ & 0.37 & 0.27 & 0.25 & 1.06 & 1.08 & 1.14 & 1.50 & 1.61 & 1.95 & 1.07 & 0.71 & 1.07 \\
\hline $\mathrm{Cd}$ & 0.19 & 0.46 & 0.44 & 4.79 & 5.46 & 5.54 & 55.94 & 38.74 & 34.51 & 19.41 & 19.36 & 22.57 \\
\hline $\mathrm{Hg}$ & BDL & BDL & BDL & BDL & BDL & BDL & BDL & BDL & BDL & BDL & BDL & BDL \\
\hline As & BDL & BDL & BDL & BDL & BDL & BDL & BDL & BDL & BDL & BDL & BDL & BDL \\
\hline $\mathrm{Zn}$ & 177.64 & 217.94 & 205.74 & 18.17 & 25.74 & 70.88 & 728.50 & 679.50 & 639 & 110.3 & 115.3 & 123.6 \\
\hline $\mathrm{Cu}$ & 159.5 & 174.50 & 156.00 & 298.5 & 310.50 & 309.5 & 331.5 & 354.5 & 399 & 30.58 & 41.24 & 47.09 \\
\hline
\end{tabular}

Table 4. Mean metal concentrations $(\mathrm{mg} / \mathrm{kg})$ in soil.

\begin{tabular}{|c|c|c|c|c|c|}
\hline \multirow{2}{*}{ LOCATION } & \multicolumn{5}{|l|}{ Metals \pm SD } \\
\hline & $\mathbf{P b}$ & Cd & Hg & Zn & $\mathbf{C u}$ \\
\hline TRANSCORP POWER (CONTROL) & $0.30 \pm 0.06$ & $0.36 \pm 0.15$ & BDL & $200.44 \pm 20.67$ & $163.33 \pm 9.55$ \\
\hline WARRI REFINERY & $1.69 \pm 0.23$ & $67.48 \pm 11.35$ & $0.45 \pm 0.40$ & $682.33 \pm 44.8$ & $361.6 \pm 30.06$ \\
\hline AMUKPE F/STATION & $0.95 \pm 0.21$ & $20.45 \pm 1.84$ & BDL & $116.41 \pm 6.71$ & $39.64 \pm 8.37$ \\
\hline PLATFORM PETROLEUM & $1.09 \pm 0.05$ & $5.26 \pm 0.53$ & BDL & $38.26 \pm 28.50$ & $306.17 \pm 6.66$ \\
\hline USEPA & 107 & 5.20 & 0.1 & 5100 & 2900 \\
\hline
\end{tabular}

Table 5. Metals concentration $\left(\mu \mathrm{g} / \mathrm{m}^{3}\right)$ in air.

\begin{tabular}{|c|c|c|c|c|c|c|c|c|c|c|c|c|}
\hline \multirow{2}{*}{ METALS } & \multicolumn{3}{|c|}{ TRANSCORP POWER (Control) } & \multicolumn{3}{|c|}{ WARRI REFINERY } & \multicolumn{3}{|c|}{ AMUKPE F/STATION } & \multicolumn{3}{|c|}{ PLATFORM PETROLEUM } \\
\hline & Feb & Mar & Apr & Feb & Mar & Apr & Feb & Mar & Apr & Feb & Mar & Apr \\
\hline $\mathrm{Pb}$ & BDL & $\mathrm{BDL}$ & $\mathrm{BDL}$ & $\mathrm{BDL}$ & 0.15 & 0.19 & 0.15 & $\mathrm{BDL}$ & BDL & BDL & BDL & BDL \\
\hline $\mathrm{Hg}$ & BDL & BDL & BDL & BDL & BDL & BDL & BDL & BDL & BDL & BDL & BDL & BDL \\
\hline As & BDL & BDL & BDL & BDL & BDL & BDL & BDL & BDL & BDL & BDL & BDL & BDL \\
\hline $\mathrm{Zn}$ & BDL & BDL & BDL & 0.50 & 0.50 & 0.50 & 1.03 & 1.10 & 1.33 & 0.53 & 0.55 & 0.17 \\
\hline
\end{tabular}

Table 6. Mean metals concentration in air $\left(\mu \mathrm{g} / \mathrm{m}^{3}\right)$ compared with guideline.

\begin{tabular}{llll}
\hline \multirow{2}{*}{ LOCATION/ GUIDELINE } & Metals \pm SD & & Zn \\
\cline { 2 - 4 } & Pb & Cd & BDL \\
\hline TRANSCORP POWER (Control) & BDL & $0.60 \pm 0.03$ & $1.15 \pm 0.16$ \\
WARRI REFINERY & $0.05 \pm 0.09$ & $1.89 \pm 0.13$ & $0.55 \pm$ \\
AMUKPE F/STATION & BDL & $0.50 \pm 0.00$ & $0.50 \pm 0.00$ \\
PLATFORM PETROLEUM & $0.11 \pm 0.10$ & $0.95 \pm 0.22$ & $0.55 \pm 0.08$ \\
WHO & 0.5 & 0.005 & N/A \\
\hline
\end{tabular}

BDL: Below detection limit; SD: Standard deviation; N/A: Not available 


\section{Discussion}

The metals concentration of the water samples from the three study locations are shown in table 1 with mean values in table 2 compared with permissible limits of WHO. Among the metals, lead $(\mathrm{Pb})$, Mercury $(\mathrm{Hg})$ and Arsenic (As) were not detected at any of the locations. Cadmium $(\mathrm{Cd})$ was only detected at Warri Refinery in the range of $0.05-0.06 \mathrm{mg} / \mathrm{L}$ and at Amukpe flow station in the range of $0.01-0.03 \mathrm{mg} / \mathrm{L}$ with corresponding means of 0.06 and $0.02 \mathrm{mg} / \mathrm{L}$ respectively.

Cadmium concentration at Warri Refinery and Amukpe flow station was higher than the control (Transcorp power station) and the WHO permissible limit of $0.01 \mathrm{mg} / \mathrm{L}$. Statistical analysis also showed that cadmium at the study locations was significantly different from the control site which showed that the two locations are polluted with cadmium. The figure below shows the concentration of cadmium in water compared with WHO standard for portable water



Figure 1. Cadmium concentrations in water compared with WHO standard.

Zinc was found present at all the locations including the control site. Warri refinery and Amukpe flow stations were higher than the control site while Platform petroleum was lower than the control site. All the locations were within the permissible limit of WHO which is $15 \mathrm{mg} / \mathrm{L}$ which implied that the water analyzes are fit for domestic purpose. Statistical analysis of the means showed that Amukpe flow station is polluted as value from this location was significantly higher than the control site.

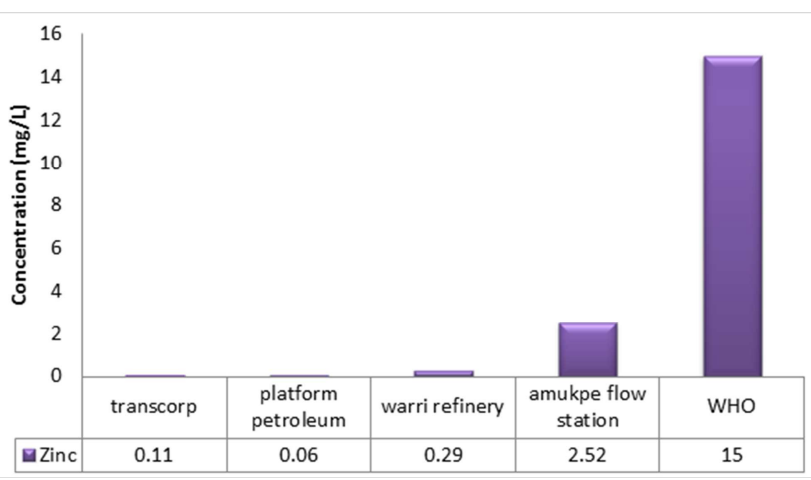

Figure 2. Zinc concentration of water compared with WHO standard.

Copper was found to widely affect the water samples at all the locations as concentrations obtained were higher than the control site and the permissible value of value of WHO which is $0.01 \mathrm{mg} / \mathrm{L}$. All the locations were contaminated with copper as statistical analysis showed that the values obtained were significantly different from the control. Copper concentration in drinking water often increase during distribution especially in systems with an acid $\mathrm{pH}$ or high carbonate waters with an alkaline $\mathrm{pH}[13]$.

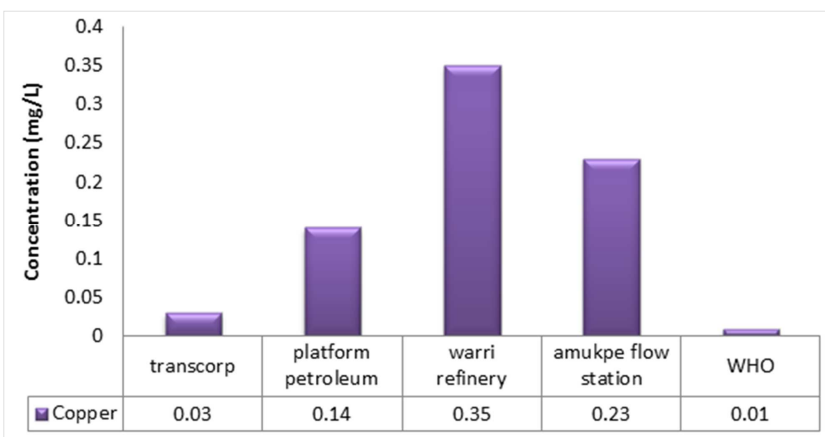

Figure 3. Copper concentration of water compared with WHO standard.

Among the heavy metals analyzed, Arsenic was found to be absent in the four study locations while mercury was only detected at Warri Refinery.

Mercury concentration at the Warri refinery was detected in the month of February and March only while it was absent in the month of April. Mercury concentrations for these two months were 0.60 and $0.75 \mathrm{mg} / \mathrm{kg}$ respectively with mean value of $0.45 \mathrm{mg} / \mathrm{kg}$. Though there was no significant difference between the locations and the control statistically, Mercury was found to pollute the soil of the Warri refinery as the mean value exceeded the maximum allowable concentration of $0.10 \mathrm{mg} / \mathrm{kg}$ provided by USEPA for uncontaminated soil and this could be attributed to leakages from petroleum tanks during loadings into the soil. The figure below shows the results of mercury concentration in soil compared with USEPA standard for uncontaminated soil.

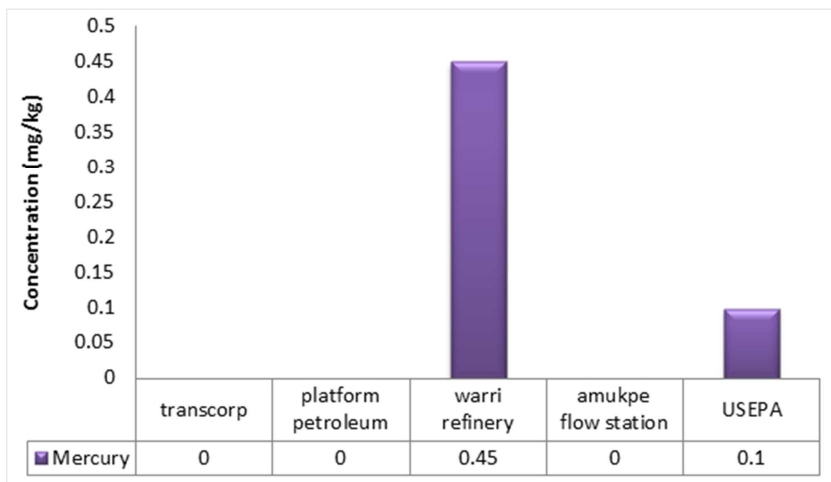

Figure 4. Mercury concentration in soil compared with USEPA standard.

When the concentration of mercury in soil exceeds the allowable limit, it causes decrease in plant height, reduces filler and causes pennicle formation, yield reduction, reduction in rate of germination, reduction in flowering and 
reduces fruit weight drastically $[14,15]$.

Lead was found present in the soil of the three study locations within the months of February and April. Among the locations, Warri refinery recorded the highest concentration while the lowest was at Amukpe flow station. Statistical analysis found all the study locations to be significantly higher than the control site and these suggested contamination. The lead concentrations could be attributed to leakages of petroleum products during loading and discharge (crude oil and petrol as the case could be) on the soil of the affected areas. The maximum allowable lead concentration for uncontaminated soil as provided by USEPA is $107 \mathrm{mg} / \mathrm{kg}$ which showed that the locations are only slightly contaminated as values obtained are within the permissible values. The figure below shows the results of lead concentration is soil.



Figure 5. Lead concentration in soil compared with USEPA standard.

Cadmium was found to be present in the soils from the four study location within the months of February and March, 2017. Pollution of the soil with cadmium was observed at Warri refinery and Amukpe flow station as values from these two sites were significantly higher than the control site. Comparisons of cadmium concentrations in this study were also found to be higher than the USEPA permissible value of $5.20 \mathrm{mg} / \mathrm{kg}$ for uncontaminated soil. Soils polluted with Cadmium are known to affect plants by reducing seed germination, decrease plant nutrient content, and reduce shoot and root $[16,17]$. Reports have shown that Cadmium accumulation in shoots/roots of plants inhibit shoot and roots growth in garlic and maize $[18,19]$.

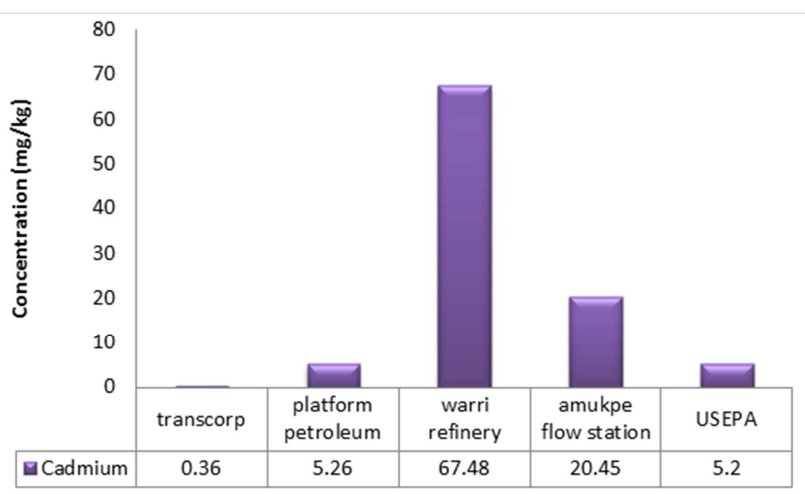

Figure 6. Cadmium concentration in soil compared with USEPA standard.
Zinc was present at all the study locations. High concentration of zinc $(682.33 \mathrm{mg} / \mathrm{kg})$ was recorded at Warri refinery. Platform petroleum with no discharge of products on soil recorded the lowest mean value of zinc to be $38.26 \mathrm{mg} / \mathrm{kg}$. Warri refinery soil thus suggested contamination as zinc concentration was significantly higher than the control site. The USEPA permissible value of zinc for uncontaminated soil is $5100 \mathrm{mg} / \mathrm{kg}$ of which the concentrations obtained are lower which also showed slight contamination in the environment. The contamination of zinc in the environment could be attributed to the indirect discharge (that is, leakages) of petroleum product on the soil as petroleum products are known to contain much amount of zinc and in the process of refining, carriage and supply, they are found to be deposited on soil indirectly through leakage from supply tanks which in-turn increases the concentration of zinc on the soil.

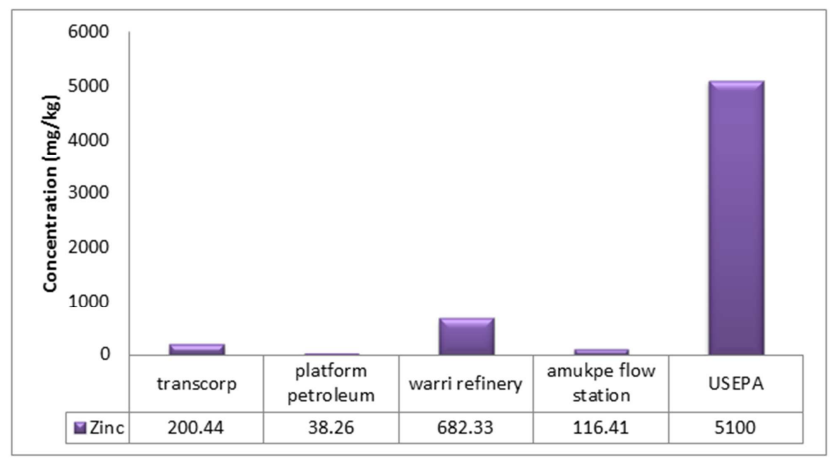

Figure 7. Zinc concentration in soil compared with USEPA standard.

Copper was found present in all the soils of the study location and was found in abundance at Platform Petroleum and Warri Refinery where most gas flaring is mostly carried out. Also, statistical analysis showed significant difference between these locations and the control. The permissible copper concentration in soil by USEPA is $2900 \mathrm{mg} / \mathrm{kg}$ for uncontaminated soil and comparison found all the locations to be contaminated with copper.

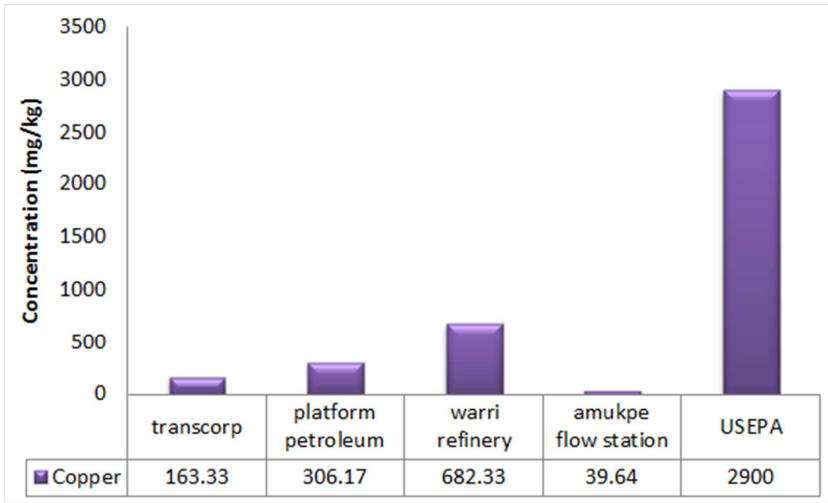

Figure 8. Copper concentration in soil compared with USEPA standard.

Copper concentration in soil whether in low or high amount have been recorded to accumulate in plant roots that lead to root malformation and reduction, plant mortality, 
reduced biomass and seed production and root growth reduction $[20,21]$.

It is worthy to state that the effect of heavy metals toxicity on soil, and plant varies according to the particular heavy metal involved in the process. Metals such as $\mathrm{Pb}, \mathrm{Cd}$, $\mathrm{Hg}$ and As which do not play any beneficial role in plant growth on soil, adverse effects have been recorded at very low concentration of these metals in growth medium [22]. For other metals which are beneficial to plants, small concentrations could actually improve plant growth and development. However, at higher concentration of these metals, reduction in plant growth has been reported for example, $50 \mathrm{mg} / \mathrm{kg}$ cobalt increases nutrients in tomatoes but conversely, at $100 \mathrm{mg} / \mathrm{kg}$ reduction in nutrients were recorded. Also, $\mathrm{Zn}$ concentration of $25 \mathrm{mg} / \mathrm{kg}$ in soil was recorded to improve growth and physiology of cluster beans. On the other hand, growth reduction and adverse effects on plants physiology started when the soil contains $50 \mathrm{mg} / \mathrm{kg}$ Zn [23].

Results of heavy metals showed that mercury and arsenic were below detection limit; lead was detected at platform petroleum in the month of March and April with concentration of 0.15 and $0.19 \mu \mathrm{g} / \mathrm{m}^{3}$ and in the month of February at Warri refinery with concentration of $0.15 \mu \mathrm{g} / \mathrm{m}^{3}$. Values obtained for lead at these locations showed no significant difference with the control site and comparison with WHO permissible value showed that the locations are safe with lead. The figure below shows the results of lead in air compared with WHO standard

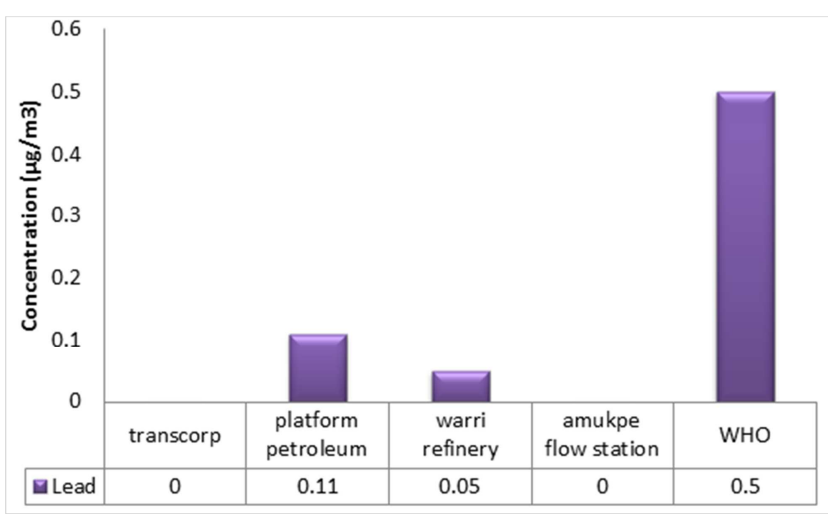

Figure 9. Lead concentration in air compared with WHO standard.

With these concentrations for the metals, it is worthy to state that long time accumulation and exposure to such concentrations would exhibit toxic effects in human which are seen in the synthesis of hemoglobin (generally cause by lead), acute and chronic damage to the nervous system, effect in the kidney, gastrointestinal tract, joint and reproductive system [24].

Comparison of the metal concentration in the environment showed that the metal loading capacity of the soil was higher followed by air while water was the least. The presence of metals in the water could be attributed to discharge of effluents and sewages on the water body. Soil is known to naturally contain metals but their high concentration could be attributed to the nature of the activities in the areas (gas flaring) which brings down acid rain and high acidity tend to increase heavy metals availability in soil [25]. The metal concentrations in the air could be attributed to the nature of industrialization which has been taking place over a long period of time.

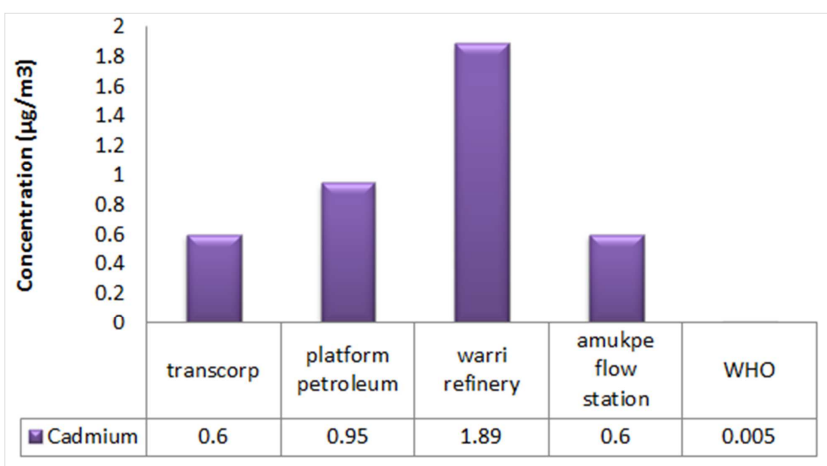

Figure 10. Cadmium concentration in air compared with WHO standard.

The metal loading capacity in the environment followed the order: soil $>$ air $>$ water and among the three, air was mostly affected followed by soil while water was the least.

\section{Conclusion and Recommendation}

Among the study locations, Platform Petroleum and Warri Refinery were found to be the most polluted with inorganic contaminants followed by Amukpe Flow Station compared to Transcorp Power Station which is the control site. The pollution of the locations followed the order: Platform Petroleum > Warri Refinery > Amukpe Flow Station > Transcorp Power Station (control site). It should be a concern to effectively manage air, water and soil for a sustainable future. The management of these natural resources should enquire methods and techniques based on sound science and careful application towards finding solution to already polluted resources. The management of air, water and soil pollution problems cannot be over emphasized hence we must avoid the reoccurrence of these pollution problems we are facing today

\section{Acknowledgements}

Staff of Delta State Polytechnic, Otefe, Oghara, Nigeria and $\mathrm{Mr}$ Bangboye Adeola of Lighthouse Petroleum Engineering Company, GRA, Effurun, Delta State, Nigeria are appreciated for the use of their laboratory facilities for chemical analysis.

\section{References}

[1] Bhatia, S. C. (2009). Environmental pollution and control in chemical process industries, Khanna Publishers, p. 163.

[2] Brimblecombe, P. (1987). The Big Smoke, A history of air pollution in London since medieval times, Routledge, London. 
[3] MacFarlarne, G. R and Burchett, M. D. (2000). Cellular distribution of copper, lead and zincin the grey mangrove, Avicennia Marina, Vierh, Journal of Aquatic Botany. 68: 4559 .

[4] Censi, P., Spoto, S. E., Sciano, F., Spronvieri, M. and Mazzola, S. (2006). Heavy metal sin coastal water system, a case study from North Western Gulf of Thailand, Chemosphere 64: 1167-1176.

[5] Ekeayanwu, C. R., Ogbuniyi, C. A. and Etienajirhevwe, O. F. (2010). Trace metal distribution in fish tissues, bottom sediments and water from Okumeshiriverin Delta State, Nigeria, Environmental Research Journal 5 (1): 6-10.

[6] Onwukeme, V. I. and Etienajirhevwe, O. I. (2014). Determination of levels of some inorganic gaseous contaminants in Warri and Effurun Environs in Delta State, Nigeria, Ethiopian Journal of Environmental Science and Management 7 (6): 619-627.

[7] Nguyen, T. N. (1997). Trace Element Analysis with application to Environmental pollutant studies in Vietnam, Ph.D Thesis, Environmental Physics Group, Physics and Engineering Physics, Chalmers University of Technology and Goteborg University, Goteborg, Sweden.

[8] Khandekar, R. N., Kelkar, D. N. and Vohrs, K. G. (1980). Lead, Cadmium, Zinc and Iron in the atmosphere of greater Bombay, Journal of Atmospheric. Environment, 14: 457-461.

[9] Canter, L. (1996). Environmental impact of agricultural production activities, Lewis Publishers Inc., Chelsea, Michrigam, pp. 169-209.

[10] Imonitie, I. O. and Ndego, E. C. (2014) Hydrochemical investigation of ground water in Obiarukwu, Delta State, Nigeria. Ethiopian Journal of Environmental Science And Management 6 (2) 311-318.

[11] Department of the Environment (DoE) (1993). Urban Air Quality in the United Kingdom, HMSO, London.

[12] Perkin Elmer Instrument (2005) Analytical Methods for Atomic Absorption Spectrophotometer. Prekin Elmer. p. 185.

[13] United States Environmental Protection Agency (USEPA) (1995), Effects of pH, DIC, orthophosphate and sulphate on drinking water cuprosolvency, USEPA, Office of Research and Development.

[14] Kibra, M. G. (2008). Effects of Mercury on some growth parameters of rice (OryzasativaL.) Journal of Soil and Environment 27 (1): 23-28.

[15] Shekar, C. H. C., Sammaiah, D., Shasthree, T. and Reddy, K. J. (2011). Efects of Mercury on Tomato growth and Yield Attributes, International Journal of Pharmaceuticals and Biological Sciences 2 (2): 358-364.

[16] Ahmad, I, Akhtar, M. J., Zahir, Z. A. and Jamil, A. (2012). Effects of Cadmium on seed germination and seedling growth of four wheat (Triticum aestirum L.) Cultivars, Pakistan Journal of Botany 44 (5): 1569-1574.

[17] Yourtchi, M. S. and Bayat, H. R. (2013). Effects of Cadmium Toxicity on Growth, Cadmium Accumulation and Micronutrient Content of Drumheat. International Journal of Agricultural and Crop Science. 6 (15): 10991103.

[18] Jiang, W., Lui, D. and Hou, W. (2001). Hyper Accumulation of Cadmium by Roots, Bulbs and Shoots of Garlic, Journal of Bio-resource Technology 76 (1): 9013.

[19] Wang, M., Zou, J., Duan, X., Jlang, W. and Liu, D (2007). Cadmium Accumulation and its Effects on Metal Uptake in Maize (zea mays L.) Journal of Bioresources and technology, 98 (1): 82-88.

[20] Kjaer, C. and Elmega and, N. (1996). Effects of Copper Sulphate on Black Bird weed (Polygonum ConvovulusL), Ecotoxicol and Environ Safety 33 (2): 110-117.

[21] Sheldon, A. R. and Menzies, N. W. (2005). The effects of Copper toxicity on growth and root morphology of Rhode Grass (Chloris Gayana Knuth) in Resin Buffered Solution Culture, Journal of Plantand Science 278 (1-2): 341-349.

[22] Kabata, A. P. (2001). Trace Elements in Soils and Plants, CRCPress, Boca Raton, Fla, USA, p. 278.

[23] Jayakumar, K., Jaleel, C. A. and Azooz, M. M. (2008). Phytochemical Changes in Green Gram (vigna radiate) under Cobalt stress, Global Journal of Molecular Sciences 3 (2): 4649.

[24] Harrop, D. O. (2002). Air Quality Assessment and Management, A Practical Guide, Spon Press, USA and Canada, p. 278

[25] Ekeanyanwu, C. R, Opia, E. E and Etienajirhevwe, O. F (2010). Trace Metals Distribution in some common tubercrops and leafy vegetables grown in the Niger Delta region of Nigeria. Pakistan Journal of Nutrition, 9 (1): 957-961. 